\title{
Analysis of Student Response to the Utilization of Chemsketch Media in Hydrocarbon Materials
}

\author{
$1^{\text {st }}$ Rosalinda Zeniona Maarebia* \\ Department of Chemistry Education \\ Universitas Musamus \\ Merauke, Indonesia \\ maarebia_fkip@unmus.ac.id
}

\author{
$2^{\text {st }}$ Novike Bela Sumanik \\ Department of Chemistry Education \\ Universitas Musamus \\ Merauke, Indonesia \\ sumanik_fkip@unmus.ac.id
}

\author{
$3^{\text {st }}$ Henie Poerwandar Asmaningrum \\ Department of Chemistry Education \\ Universitas Musamus \\ Merauke, Indonesia \\ poerwandar@unmus.ac.id
}

\begin{abstract}
Learning hydrocarbons using Chemsketch media is a new thing learned by students of SMA Negeri 2 Merauke. Research using Chemsketch media aims to analyze how students respond to the use of Chemsketch media in the learning process, especially for hydrocarbon material. The data obtained from this study were in the form of student response questionnaire data. The data obtained were analyzed using descriptive analytical methods to obtain answers to the problems contained in the study. Based on the research results obtained, it is known as many as $\mathbf{7 8 . 3 9 \%}$ of students gave a positive response to the use of Chemsketch media because learning activities using Chemsketch media make students more active and better understand Hydrocarbon material.
\end{abstract}

Keywords: chemsketch, hydrocarbon, descriptive analytical

\section{INTRODUCTION}

The progress of a nation is inseparable from the role of education as a means of building the nation's character. An intelligent society will give the nuances of an intelligent life as well, and progressively will be formed independence and creativity. The most important and fundamental principle in education itself is that learning applied must be able to change mindsets and bring renewal to students in receiving the information they get [1]. Students are not just accepting material in the form of lectures, dialogues where students just sit listening without being trained in their creativity. Students themselves must build their knowledge. And here the teacher's role is to bring students to an understanding of higher material [2]. Students are a human component that occupies a central position in the learning process [3]. Meaningful learning will not be realized only by listening to lectures or reading books about the experiences of others [4]. Based on this there are two challenges that must be faced by a teacher, the first challenge is the change in perceptions about learning, and the second challenge is the existence of information technology that shows an extraordinary development so that this century is known as the age of technology [5]. Therefore facing the development of this technological age the participation of teachers is also required to be able to use technology-based learning media in learning. Teachers are required to be able to create integrated creative and innovative learning. In the process of learning chemistry, a teacher has an important role in conveying information, training skills and guiding student learning so that teachers are required to have certain qualifications and competencies. In accordance with the conditions in the field many students still consider chemistry a difficult and complicated subject to understand, even many students who find it difficult to understand chemistry itself, thus impacting on the low achievement of students Success in learning is largely determined by how far the teacher is able to eliminate or complete problems in learning [6]. To make it easier for students to understand the concept of chemistry well, a learning media is needed. Media can make learning easier for students to digest. The use of media in learning can increase new desires and interests, increase motivation and stimulation of learning activities, and even influence psychologically on students [7]. Therefore we need a learning design that supports the development of learning technology which is then used as a reference in developing computer-based learning media [8]. One of the learning designs using computer media is Chemsketch's media. Chemsketch is an application often used by chemists to write down chemical structures. Chemsketch as a computer-based learning media is a software for modeling and visualizing the structure of chemical compounds [9]. So that Chemsketch is appropriate to be used in hydrocarbon learning which can provide a three-dimensional picture. Three-dimensional media used in teaching are real objects that are too big, too far, too small, too expensive, too rare, or too difficult to be brought into the classroom and studied by students in their original form [10]. With this Chemsketch teacher can easily manipulate and change it so that it can be as a time efficiency in the learning process. Therefore Chemsketch's media is used in learning to see how students respond to this media when it is applied in hydrocarbon material. Aside from being a three-dimensional visualization Chemsketch is also used to calculate the molar volume of the addition of additive atoms obtained using a database of density and molecular weight [11].

\section{RESEARCH METHODS}

The research method used is descriptive analysis in which this method serves to describe or give a picture of the object under study through the data or samples that have been collected as they are then processed and analyzed to draw conclusions.

The study was conducted to find out how students' responses to the use of the media Chemsketch in the process of learning hydrocarbons. The study was conducted at SMA Negeri II Merauke with a sample of 28 students. The data analyzed were questionnaire responses of students towards the use of Chemsketch media in the learning process. The data that has been collected is then processed to analyze the 
data in descriptive analysis. Based on the data description, it can be seen how students respond after the application of the media.

\section{RESUlt AND DISCUSSION}

Student response data on the use of Chemsketch media is known from the questionnaire distribution. Questionnaire students' responses to the use of Chemsketch consisted of 20 statements and were given to 28 respondents. The purpose of this data description is to find out how students respond to the use of Chemsketch in learning hydrocarbons as a threedimensional visualization in chemical structures. Data processing uses percentage form. By describing the results of the questionnaire in the form of a percentage to find out the percentage of each item and the cumulative percentage of each indicator. The description of the percentage data for each item of statement and the cumulative percentage for each indicator of the student response questionnaire is described as follows:

\section{A. Percentage Of Response Questionnaire Data For} Indicator I (Compatibility Of Media With Material)

Based on table 1, it was found that students' responses to the use of Chemsketch media on the media suitability indicator with material that is equal to $30.80 \%$ expressed strongly agree with the number of frequencies 69 and $35.71 \%$ stated agreed with the number of frequencies 80 . And for the overall percentage of student responses to the use of Chemsketch media from indicator 1 it was found that from 28 respondents with 8 statements in indicator 1 obtained a frequency number of 224 for all answer choices, and a total score of 860 at a maximum score of 1120 . Calculation of the percentage for indicator 1 obtained a value of $76.78 \%$ so that it means that there is a match between media used in this case Chemsketch with hydrocarbon material, and the percentage obtained is classified as strong.

TABLE I. Cumulative Percentage OF Student Responses INDICATOR I

\begin{tabular}{|c|c|c|c|c|c|}
\hline $\begin{array}{c}\text { Item } \\
\text { number }\end{array}$ & Score & Frequency & $\begin{array}{c}\text { Percentage } \\
\text { of each } \\
\text { item } \\
\end{array}$ & Total & Percentage \\
\hline \multirow{5}{*}{$\begin{array}{c}1,3,9 \\
14,16, \\
17,18 \\
19\end{array}$} & 5 & 69 & 30.81 & 345 & 40.12 \\
\hline & 4 & 80 & 35.72 & 320 & 37.21 \\
\hline & 3 & 55 & 24.55 & 165 & 19.19 \\
\hline & 2 & 10 & 4.46 & 20 & 2.32 \\
\hline & 1 & 10 & 4.46 & 10 & 1.16 \\
\hline \multicolumn{2}{|c|}{ Total } & 224 & 100 & 860 & 100 \\
\hline \multicolumn{2}{|c|}{ Highest score } & \multicolumn{4}{|c|}{5} \\
\hline \multicolumn{2}{|c|}{$\begin{array}{l}\text { Number of } \\
\text { Statements }\end{array}$} & \multicolumn{4}{|c|}{8} \\
\hline \multicolumn{2}{|c|}{$\begin{array}{l}\text { Number of } \\
\text { Respondents }\end{array}$} & \multicolumn{4}{|c|}{28} \\
\hline \multicolumn{2}{|c|}{ Maximum score } & \multicolumn{4}{|c|}{1120} \\
\hline \multicolumn{2}{|c|}{ Percentage } & \multicolumn{4}{|c|}{$76.78 \%$} \\
\hline
\end{tabular}

\section{B. Percentage Of Response Questionnaire Data For}

Indicator Ii (Ease Of Use Of Chemsketch Media

Based on table 2, it was found that students' responses to the use of Chemsketch in indicator 2 for ease of use of the media, namely $30 \%$ expressed strongly agree with the number of frequencies 42 and $37.85 \%$ stated agreed with the number of frequencies 53 . Based on the percentage obtained it is known that most students easily use Chemsketch media.
And for the overall percentage of students' responses to the use of the Chemsketch media from indicator 2, it was found that from 28 respondent with 5 statements on indicator II, the number of frequencies was 140 for all answer choices, and the total score was 549 at a maximum score of 700 .

TABLE II. CUMULATIVE PERCENTAGE OF STUDENT RESPONSES INDICATOR II

\begin{tabular}{|c|c|c|c|c|c|}
\hline $\begin{array}{c}\text { Item } \\
\text { number }\end{array}$ & Score & Frequency & $\begin{array}{c}\text { Percentage } \\
\text { of each } \\
\text { item }\end{array}$ & Total & Percentage \\
\hline \multirow{5}{*}{$\begin{array}{c}6,8, \\
12,13, \\
20\end{array}$} & 5 & 42 & 30 & 210 & 38.25 \\
\hline & 4 & 53 & 37.86 & 212 & 38.61 \\
\hline & 3 & 38 & 27.14 & 114 & 20.77 \\
\hline & 2 & 6 & 4.29 & 12 & 2.19 \\
\hline & 1 & 1 & 0.71 & 1 & 0.18 \\
\hline \multicolumn{2}{|c|}{ Total } & 140 & 100 & 549 & 100 \\
\hline \multicolumn{2}{|c|}{ Highest score } & \multicolumn{4}{|c|}{5} \\
\hline \multicolumn{2}{|c|}{$\begin{array}{l}\text { Number of } \\
\text { Statements }\end{array}$} & \multicolumn{4}{|c|}{5} \\
\hline \multicolumn{2}{|c|}{$\begin{array}{c}\text { Number of } \\
\text { Respondents }\end{array}$} & \multicolumn{4}{|c|}{28} \\
\hline \multicolumn{2}{|c|}{$\begin{array}{l}\text { Maximum } \\
\text { score }\end{array}$} & \multicolumn{4}{|c|}{700} \\
\hline \multicolumn{2}{|c|}{ Percentage } & \multicolumn{4}{|c|}{$78.43 \%$} \\
\hline
\end{tabular}

The percentage calculation for indicator II was $78.43 \%$, meaning that students were motivated to use chemsketch in hirocarbon material because of its easy use for visulisation of chemical structures in three dimensions. Students' understanding of chemistry is very abstract especially chemistry which is identical to chemical structures, molecules and formulas so many students assume that learning chemistry is difficult and boring because of their lack of understanding. With this media it is expected that students can actively innovate and be creative so that by themselves students can determine their chemical structure and naming easily. And from the results of the research that has been analyzed, it is obtained a very good percentage with the percentage value obtained for indicators regarding the ease of use of Chemsketch media classified as strong.

\section{Percentage Of Response Questionnaire Data For Indicator Iii (Interest In The Use Of Chemsketch Media)}

Based on table 3, it was found that students' responses to the use of Chemsketch in indicator III for interest in media use, namely $33.2 \%$ expressed strongly agree with the number of frequencies 65 and $27.55 \%$ stated agreed with the number of frequencies 54 while $34.69 \%$ stated neutral with a frequency number of 68 for negative responses obtained a percentage of $4.08 \%$ stated disagree with the number of frequencies 8 and $0.51 \%$ stated strongly disagree with the number of frequencies 1 . Based on the percentage obtained it is known that most students have an interest in the learning process of hydrocarbon material using Chemsketch media.

TABLE III. CUMULATIVE PERCENTAGE OF STUDENT RESPONSES INDICATOR

\begin{tabular}{|c|c|c|c|c|c|}
\hline $\begin{array}{c}\text { Item } \\
\text { number }\end{array}$ & Score & Frequency & $\begin{array}{c}\text { Percentage } \\
\text { of Each } \\
\text { item }\end{array}$ & Total & Percentage \\
\hline \multirow{3}{*}{$2,4,5}$, & 5 & 65 & 33.16 & 325 & 42.65 \\
\cline { 2 - 6 } 7,10, & 4 & 54 & 27.56 & 216 & 28.34 \\
\cline { 2 - 6 } 11,15 & 2 & 68 & 34.69 & 204 & 26.78 \\
\cline { 2 - 6 } & 1 & 8 & 4.08 & 16 & 2.1 \\
\hline
\end{tabular}




\begin{tabular}{|c|c|c|c|c|}
\hline Total & 196 & 100 & 762 & 100 \\
\hline Highest score & \multicolumn{4}{|c|}{5} \\
\hline $\begin{array}{l}\text { Number of } \\
\text { Statements }\end{array}$ & \multicolumn{4}{|c|}{7} \\
\hline $\begin{array}{l}\text { Number of } \\
\text { Respondents }\end{array}$ & \multicolumn{4}{|c|}{28} \\
\hline Maximum score & \multicolumn{4}{|c|}{980} \\
\hline Percentage & \multicolumn{4}{|c|}{$77.76 \%$} \\
\hline
\end{tabular}

And for the overall percentage of student responses to the use of Chemsketch media from indicator III is shown in the table it was found that from 28 respondents with 7 statements on indicator III obtained a total frequency of 196 for all answer choices, and a total score of 762 at a maximum score of 980. Calculation of the percentage for indicator III obtained a value of $77.76 \%$ so that means that students are interested in the media Chemsketch in the matter of hirocarbons and the acquisition of this percentage belong to the strong category.

\section{The cumulative percentage of student responses throughout the statement items}

From the overall statement items, a total of 20 statements obtained a percentage of $78.39 \%$ so that from the recapitulation the percentage of students' responses to the use of Chemsketch media in the learning process in the hydrocarbon material was classified as good and students were motivated in using the Chemsketch learning media.

TABLE IV. THE CUMULATIVE PERCENTAGE OF STUDENTS' RESPONSES TO ALL ITEMS

\begin{tabular}{|c|c|c|c|c|}
\hline $\begin{array}{c}\text { Item } \\
\text { number }\end{array}$ & Score & Frequency & Total & Percentage \\
\hline \multirow{3}{*}{$1-20$} & 5 & 176 & 880 & 40.09 \\
\cline { 2 - 5 } & 4 & 187 & 748 & 34.08 \\
\cline { 2 - 5 } & 3 & 161 & 483 & 22.00 \\
\cline { 2 - 5 } & 2 & 24 & 72 & 3.28 \\
\cline { 2 - 5 } & 1 & 12 & 12 & 0.55 \\
\hline \multicolumn{2}{|c|}{ Total } & 196 & 2195 & 100 \\
\hline \multicolumn{3}{|c|}{ Highest score } & \multicolumn{3}{|c|}{20} \\
\hline Number of Statements & \multicolumn{3}{|c}{2800} \\
\hline \multicolumn{3}{|c|}{ Number of } \\
Respondents
\end{tabular}

\section{CONCLUSION}

Based on research results which were known that results of student response to the use of chemsketch media in learning hydrocarbons contained from 20 statements of statement. Comparison of percentage by each indicator which the first indicator $76.78 \%$ strong category, second indicators $78.43 \%$ strong category, third indicators $77.76 \%$ strong category. And from the entire state of the statement which has obtained a percentage of the whole $78.39 \%$ is strong category. The selection based on interpretation of percentage of questionnaire is liked in a strong category. This shows that a large proportion of students are motivated and interested in the use of the chemsketch media in the learning process.

\section{ACKNOWLEDGMENT}

Thank you to the Principal, Field Study Teacher and students of SMA Negeri II Merauke.

\section{REFERENCES}

J. Ariyawati, M.A.P, Waluyo, J. Prihatin, "Analisis Respon Siswa Terhadap Model Pairs, Investigation And Communication (PIC) Dalam Pembelajaran IPA (Analysis of Student Responses to the PAIRS Model, Investigation and Communication (PIC) in Science Learning)," pp. 6-10, 2017.

[2] R. E. Slavin, Cooperative Learning Teori Riset dan Praktek (Cooperative Learning Research Theory and Practice). Bandung: Nusa Media, 2005.

[3] Sardiman, Interaksi dan Motivasi Belajar Mengajar (Interaction and Teaching Learning Motivation). Jakarta: PT. Raja Grafindo Persada, 2007.

[4] Trianto, Model Pembelajaran Terpadu (Integrated Learning Model). Jakarta: Bumi Aksara, 2015.

[5] S. Hadijah, "Analisis Respon Siswa Dan Guru Terhadap Penggunaan Multimedia Interaktif Dalam Proses Pembelajaran Matematika (Analysis of Student and Teacher Responses to the Use of Interactive Multimedia in the Mathematics Learning Process)," vol. 5, no. 2, p. 176, 2018.

[6] C. P. K. Sitepu, "Pengaruh Pemanfaatan Media Chemsketch Dalam Pembelajaran Yang Menggunakan Metode Resitasi Terhadap Motivasi Dan Hasil Belajar Kimia Di SMK Kelas XI (The Effect of Using Chemsketch Media in Learning Using the Recitation Method on the Motivation and Learning Outcomes of Chemistry in Senior High School Class XI)," J. Ilm.

"INTEGRITAS," vol. 2, no. 1, 2016.

[7] Sukiman, pengembangan media pembelajaran (Learning Media Development). Yogyakarta: Pustaka Insan Madani, 2012.

[8] Roza Linda 1*; Herdini1; Zera Rahmaputri1, "Multimedia interaktif berbasis autoplay media studio 8 untuk mata pelajaran kimia pokok bahasan laju reaksi untuk kelas XI SMA/MA (Interactive multimedia based on autoplay media studio 8 for chemistry subjects, the subject of reaction rates for class XI SMA / MA)," vol. 9, no. 3, pp. 341-346, 2017.

[9] H. H. Utami and M. Anwar, "Pengaruh Chemsketch Dalam Penulisan Struktur Kimia Pada Metode Resitasi Terhadap Hasil Belajar Siswa Materi Pokok Ikatan Kimia (The Influence of Chemsketch in Writing Chemical Structures in the Recitation Method on Student Learning Outcomes Main Material of Chemical Bonds)," J. Penelit. Pendidik. Insa., vol. Vol.20, no. No.2, pp. 96-100, 2017.

[10] R. A. Nana Sudjana, Media Pengajaran (Teaching Media). Bandung: Sinar Baru Algensindo, 2002.

[11] K. Laxmi, "Chemsketch Study of Phenobarbital: An Antiepileptic Drug," Int. J. Comput. Theor. Chem., vol. 5, no. 3, p. 25, 2017. 